\title{
Hubungan Tingkat Kecemasan dalam Menghadapi Objective Structured Clinical Examination (OSCE) dengan Kelulusan OSCE pada Mahasiswa Fakultas Kedokteran Universitas
} Andalas

\author{
Dinda Putri Amir ${ }^{1}$, Detty Iryani ${ }^{2}$, Laila Isrona ${ }^{3}$
}

\begin{abstract}
Abstrak
Kecemasan adalah normal terjadi dalam kehidupan, namun kecemasan dapat menjadi abnormal jika respons terhadap stimulus berlebihan. Pada mahasiswa, kecemasan berpengaruh terhadap proses pendidikan. OSCE merupakan salah satu bagian dari ujian komprehensif yang menguji keterampilan medis mahasiswa yang akan memasuki kepaniteraan klinik. Ujian ini hampir sama dengan ujian skills lab, tapi materi ujian lebih banyak dan setting ujian juga berbeda sehingga situasi tersebut menimbulkan kecemasan pada mahasiswa menjelang OSCE. Tujuan penelitian ini adalah menentukan hubungan tingkat kecemasan dalam menghadapi OSCE dengan kelulusan OSCE pada mahasiwa FK Unand. Jenis penelitian ini adalah deskriptif analitik dengan sampel sebanyak 34 orang. Data diperoleh melalui wawancara kepada peserta OSCE menggunakan kuesioner Hamilton Rating Scale for Anxiety (HRS-A) dan Bagian Akademik FK Unand yang selanjutnya dianalisis melalui uji korelasi Gamma dan Somers'd. Hasil penelitian ini didapatkan nilai koefisien korelasi $(r)$ sebesar $-0,106$ dan nilai signifikansi $p>0,05$. Berdasarkan hasil penelitian dapat disimpulkan bahwa tidak terdapat hubungan yang bermakna antara tingkat kecemasan dalam menghadapi OSCE dengan kelulusan OSCE pada mahasiwa FK Unand.
\end{abstract}

Kata kunci: kecemasan, ujian, OSCE, HRS-A

\section{Abstract}

Anxiety normally occurs in life, but anxiety can become abnormal if the response to the stimulus is excessive. In student, anxiety affects the educational process. OSCE is a part of comprehensive exam that examine medical skills of the students who will enter their clinical stage. Although this exam is similiar like skills lab exam but the matters of exam is more complex and the setting of exam is different too, so these situations cause anxiety in students toward OSCE. The objective of this study was to determine the correlation between anxiety level in facing OSCE to students' graduation of OSCE in Faculty of Medicine Andalas University. This study was a descriptive analytical and total sample of 34 people. Data were collected through interviewing the students use the questionnaire of Hamilton Rating Scale for Anxiety (HRS-A) and Academic Department of Faculty of Medicine Andalas University. It was analyzed by Gamma and Somerd's correlation test. The result of this study found a correlation coefficient $(r)$ is $-0,106$ and level of significance (p) $>0,05$. Based on the result, it can be concluded that there is no correlation between anxiety level in facing OSCE with students' graduation of OSCE in Faculty of Medicine Andalas University.

Keywords: anxiety, exam, OSCE, HRS-A

Affiliasi penulis: 1. Pendidikan Dokter FK UNAND (Fakultas Kedokteran Universitas Andalas Padang, 2. Bagian Fisiologi FK UNAND, 3. Bagian Pendidikan Kedokteran FK UNAND.
Korespondensi: Dinda Putri Amir,

email : dindaputriy@yahoo.com, Telp: 085265208125 


\section{PENDAHULUAN}

Ujian merupakan suatu rangkaian persoalan, pertanyaan-pertanyaan dan latihan untuk menentukan tingkat pengetahuan, kemampuan, bakat atau kualifikasi peserta didik. ${ }^{1}$ Mahasiswa kedokteran sebagai peserta didik juga tidak terlepas dari ujian. Pendidikan kedokteran dasar terdiri dari dua tahap, yaitu tahap preklinik dan tahap kepaniteraan klinik. ${ }^{2}$ Ujian komprehensif merupakan exit exam dari tahap preklinik ke tahap kepaniteraan klinik. ${ }^{3}$

Ujian komprehensif terdiri dari dua jenis ujian yaitu ujian tulis berupa Multiple Choice Question (MCQ) dan ujian keterampilan/perilaku berupa Objective Structured Clinical Examination (OSCE). ${ }^{3}$ OSCE sebagai instrumen penguji keterampilan klinis mahasiswa kedokteran sudah sejak tahun 1979 digunakan. ${ }^{4}$ FK Unand sejak tahun 2008 sudah menyelenggarakan OSCE dan masih berlangsung hingga kini. ${ }^{3}$

Ujian merupakan salah satu stressor yang memicu timbulnya kecemasan pada mahasiwa. Kecemasan mempengaruhi organ viseral dan motorik, pikiran, persepsi, dan pembelajaran. ${ }^{5}$ Oleh sebab itu, kecemasan dapat menghambat fungsi kognitif yang berpengaruh pada performa ketika ujian.

Tingkat kecemasan yang dialami masingmasing individu ketika menghadapi ujian adalah berbeda-beda sehingga dibutuhkan suatu indikator untuk mengukur kecemasan yang dialami seseorang, salah satunya dengan menggunakan kuesioner Hamilton Rating Scale for Anxiety (HRS-A). HRS-A mengelompokkan tingkat kecemasan menjadi lima tingkatan, yaitu tidak ada kecemasan, kecemasan ringan, kecemasan sedang, kecemasan berat, dan kecemasan berat sekali. $^{6}$

Pada tahun ajaran (TA) 2012/2013 mahasiswa angkatan 2009 merupakan mahasiswa tingkat akhir yang akan mengikuti OSCE. Menurut hasil penelitian Arief et al pada tahun 2003, akibat materi ujian yang banyak maka pelaksanaan ujian menuntut peserta harus bertindak cepat (lebih kurang lima sampai sepuluh menit perstasiun), tepat, dan lengkap agar mendapatkan nilai yang bagus, kemungkinan akan menimbulkan kecemasan yang lebih tinggi ketika menghadapi ujian tersebut. ${ }^{7}$ Berdasarkan penelitian Brand dan Schoonheim (2009) menyimpulkan bahwa kecemasan tersebut kemungkinan disebabkan karena selama OSCE peserta ujian diawasi dan diobservasi secara terus menerus, serta durasi ujian serta interaksi antara penguji dan peserta ujian juga mempengaruhi tingkat kecemasan mereka. ${ }^{8}$

Penelitian terdahulu diketahui bahwa OSCE menginduksi kecemasan lebih tinggi dibandingkan jenis ujian lainnya. ${ }^{8,9}$ Penelitian yang pernah dilakukan juga menemukan bahwa mahasiswa yang mengikuti OSCE hanya mengalami kecemasan yang rendah. ${ }^{9}$

Kecemasan yang timbul ketika menghadapi ujian akan mempengaruhi performa mahasiswa yaitu mereka dengan tingkat kecemasan yang lebih rendah performanya akan lebih baik dibanding mereka yang mengalami kecemasan sedang dan tinggi. Penelitian lain menemukan bahwa mahasiswa yang mengalami kecemasan sedang mampu menampilkan performa yang lebih baik dalam ujian. ${ }^{10}$ Berdasarkan hasil penelitian tersebut, perlu untuk diteliti bagaimana hubungan antara tingkat kecemasan mahasiswa FK Unand dalam menghadapi OSCE dengan kelulusan.

\section{METODE}

Jenis Penelitian ini adalah deskriptif analitik dengan pendekatan cross sectional. Populasi penelitian yaitu mahasiswa FK Unand yang akan mengikuti OSCE IV TA 2012/2013 dengan besar sampel yaitu seluruh peserta OSCE yang termasuk ke dalam kriteria inklusi. Kriteria inklusi yaitu mahasiswa yang terdaftar sebagai peserta OSCE dan mahasiswa yang bersedia menjadi responden. Kriteria eksklusi yaitu mahasiswa yang sakit atau tidak hadir ketika OSCE dan mahasiswa yang tidak berasal dari Angkatan 2009. Variabel independen ialah tingkat kecemasan dan variabel dependen dalam penelitian ini adalah dan kelulusan OSCE. Langkah-langkah pengolahan data meliputi editing, coding, data entry, dan cleaning. Analisis data menggunakan analisis univariat dan bivariat. Pada analisis bivariat dilakukan dengan menggunakan uji korelasi. 
HASIL

\section{Hasil Analisis Univariat}

Tabel 1. Karakteristik peserta OSCE berdasarkan jenis kelamin, frekuensi mengikuti OSCE, kelulusan OSCE dan tingkat kecemasan menghadapi OSCE

\begin{tabular}{ccc}
\hline Karakteristik & $\mathbf{n}$ & $\%$ \\
\hline Jenis Kelamin & 4 & 11.8 \\
Laki-laki & 30 & 88.2 \\
Perempuan & & \\
Frekuensi mengikuti OSCE & 34 & 100 \\
1 kali & 0 & 0 \\
$>\quad 1$ kali & & \\
Lelulusan OSCE & 22 & 64.7 \\
Lulus & 12 & 35.3 \\
Tidak lulus & & \\
Tingkat kecemasan & 26 & 76.5 \\
Tidak cemas & 8 & 23.5 \\
Cemas ringan & 0 & 0 \\
Cemas sedang & 0 & 0 \\
Cemas berat & 0 & 0 \\
Cemas berat sekali &
\end{tabular}

Berdasarkan Tabel 1 diketahui bahwa sebagian besar responden adalah perempuan (88\%). Seluruh responden mengikuti OSCE untuk yang pertama kali. Sebagian besar responden lulus OSCE (64.7\%). Sebagian besar responden tidak mengalami kecemasan dalam menghadapi OSCE (76.5\%).

Tabel 2. Karakteristik peserta OSC berdasarkan jenis kelamin dan tingkat kecemasan yang dialami

\begin{tabular}{lllll}
\hline Jenis & \multicolumn{2}{c}{ Tidak cemas } & \multicolumn{2}{c}{ Cemas ringan } \\
kelamin & $\mathbf{n}$ & $\%$ & $\mathbf{n}$ & $\%$ \\
\hline Laki-laki & 3 & 75 & 1 & 25 \\
Perempuan & 23 & 76.7 & 8 & 23.3 \\
\hline
\end{tabular}

Berdasarkan Tabel 2 diketahui bahwa sebagian besar responden baik laki-laki (75\%) maupun perempuan $(76.7 \%)$ tidak mengalami kecemasan dalam menghadapi OSCE.

Tabel 3. Gambaran tingkat kecemasan peserta OSCE berdasarkan kelulusan OSCE

\begin{tabular}{llcll}
\hline $\begin{array}{l}\text { Tingkat } \\
\text { kecemasan }\end{array}$ & \multicolumn{3}{c}{ Kelulusan OSCE } \\
& \multicolumn{2}{c}{ Lulus } & \multicolumn{2}{c}{ Tidak lulus } \\
\cline { 2 - 5 } & $\mathbf{n}$ & $\%$ & $\mathbf{n}$ & $\%$ \\
\hline Tidak cemas & 16 & 61.5 & 10 & 38.5 \\
Cemas ringan & 6 & 75 & 2 & 25 \\
Cemas sedang & 0 & 0 & 0 & 0 \\
Cemas berat & 0 & 0 & 0 & 0 \\
\hline
\end{tabular}

Berdasarkan Tabel 3 diketahui sebagian besar responden yang mengalami kecemasan ringan lulus OSCE (75\%).

\section{Hasil Analisis Bivariat}

Tabel 4. Hubungan antara tingkat kecemasan dalam menghadapi OSCE dan kelulusan OSCE

\begin{tabular}{|c|c|c|c|c|c|c|}
\hline \multirow{3}{*}{$\begin{array}{l}\text { Tingkat } \\
\text { kecemasan }\end{array}$} & \multicolumn{4}{|c|}{ Kelulusan OSCE } & \multirow[t]{3}{*}{$\mathbf{r}$} & \multirow[t]{3}{*}{$p$} \\
\hline & \multicolumn{2}{|c|}{ Lulus } & \multicolumn{2}{|c|}{ Tidak lulus } & & \\
\hline & $\mathbf{n}$ & $\%$ & $\mathbf{n}$ & $\%$ & & \\
\hline $\begin{array}{l}\text { Tidak } \\
\text { cemas }\end{array}$ & 16 & 61,5 & 10 & 38.5 & & \\
\hline $\begin{array}{l}\text { Cemas } \\
\text { ringan }\end{array}$ & 6 & 75 & 2 & 25 & & \\
\hline $\begin{array}{l}\text { Cemas } \\
\text { sedang }\end{array}$ & 0 & 0 & 0 & 0 & -.106 & 0,461 \\
\hline $\begin{array}{l}\text { Cemas } \\
\text { berat }\end{array}$ & 0 & 0 & 0 & 0 & & \\
\hline $\begin{array}{l}\text { Cemas } \\
\text { berat } \\
\text { sekali }\end{array}$ & 0 & 0 & 0 & 0 & & \\
\hline
\end{tabular}

Berdasarkan Tabel 4 dapat dilihat bahwa dari hasil uji korelasi Gamma dan Somers'd didapatkan koefisien korelasi $(r)=-0.106$ yang menunjukkan bahwa korelasi antara kecemasan menghadapi OSCE dengan kelulusan OSCE pada mahasiswa FK Unand adalah tidak ada/sangat lemah dengan arah korelasi negatif. Sedangkan nilai $p$ yang diperoleh yaitu sebesar $0.461 \quad(p>0,05)$. Hal ini berarti bahwa tidak terdapat hubungan yang bermakna antara tingkat kecemasan mahasiswa FK Unand dalam menghadapi OSCE dengan kelulusan OSCE.

\section{PEMBAHASAN}

\section{Karakteristik Mahasiswa yang Mengikuti OSCE}

Tiga puluh tujuh orang yang mengikuti OSCE IV TA 2012/2013, sejumlah 36 orang bersedia menjadi responden, namun memenuhi kriteria inklusi hanya 34 orang. Berdasarkan hasil uji statistik terlihat bahwa jumlah responden perempuan lebih banyak dari responden laki-laki yaitu perempuan berjumlah 30 orang $(88,2 \%)$ dan laki-laki sebanyak empat orang $(11,8 \%)$. Pada tabel uji statistik diketahui bahwa dari empat responden laki-laki, tiga diantaranya tidak mengalami kecemasan (75\%) dan satu orang 
mengalami kecemasan ringan (25\%) dalam menghadapi OSCE, sedangkan untuk responden perempuan diketahui sebanyak 23 orang tidak mengalami kecemasan $(76,7 \%)$ dan tujuh orang mengalami kecemasan ringan dalam menghadapi OSCE (23,3\%). Berdasarkan penelitian para ahli, Brizendine (2006) dalam bukunya yang berjudul the female brain menyatakan bahwa remaja perempuan hampir dua kali lebih mungkin menderita depresi dan kecemasan dibandingkan remaja laki-laki. Para ahli syaraf menemukan bahwa kepekaan ini dipengaruhi oleh gen, estrogen, progesteron dan fenomena bawaan biologis otak. Selain itu juga diketahui bahwa banyak variasi gen dan sirkuit otak yang dipengaruhi oleh estrogen dan serotonin diduga meningkatkan risiko depresi pada perempuan. ${ }^{11}$

Penelitian oleh Agustiar dan Asmi (2010) telah membuktikan bahwa kecemasan ketika ujian nasional pada siswa perempuan cenderung lebih tinggi dibandingkan pada siswa laki-laki. ${ }^{12}$ Penelitian oleh Mariyam dan Kurniawan (2008) juga menemukan bahwa sebagian responden laki-laki hanya mengalami kecemasan ringan, sementara pada responden perempuan ditemukan tingkat kecemasan yang lebih tinggi. ${ }^{13}$

Berdasarkan frekuensi mengikuti OSCE diketahui bahwa semua mahasiswa yang mengikuti OSCE IV TA 2012/2013 menyatakan bahwa ini merupakan OSCE pertama yang mereka ikuti, sehingga dapat disimpulkan bahwa OSCE tersebut merupakan pengalaman pertama bagi semua responden. Kecemasan yang dialami beberapa responden merupakan reaksi terhadap suatu hal yang mereka belum pernah alami sebelumnya.

Hasil penelitian Fidment (2012) melaporkan bahwa tidak ada perbedaan yang signifikan antara mahasiswa yang pertama kali mengikuti OSCE dengan mahasiswa yang pernah mengikuti OSCE sebelumnya. ${ }^{14}$ Berdasarkan hal tersebut kekerapan mengikuti OSCE tidak berpengaruh terhadap kecemasan yang dialami responden.

\section{Karakteristik Tingkat Kecemasan Mahasiswa yang Mengikuti OSCE}

Hasil uji statistik menunjukkan bahwa peserta ujian yang tidak mengalami kecemasan dalam menghadapi OSCE sebanyak 26 orang (76,5\%), cemas ringan sejumlah delapan orang $(23,5 \%)$, dan tidak ada responden yang mengalami cemas sedang, berat, atau berat sekali. Penelitian ini dilaksanakan sehari sebelum OSCE.

Sebagian besar responden tidak mengalami kecemasan, untuk mengetahui bagaimana hubungan antara selang waktu ujian dengan tingkat kecemasan peserta OSCE perlu dilakukan penelitian lebih lanjut. Kemudian alasan ketidakcemasan sebagian besar peserta OSCE ini kemungkinan juga dipengaruhi oleh persiapan mereka sebelum ujian, sehingga perlu dilakukan penelitian lebih lanjut. Akan tetapi penelitian Fidment (2012) membuktikan bahwa persiapan sebelum ujian merupakan kunci strategi coping untuk beradaptasi dengan kecemasan yang dialami. Dalam situasi tertentu, kecemasan dapat menjadi efek yang positif bagi mahasiswa dalam memfokuskan dan menggunakan kemampuan strategi coping untuk memanajemen keadaan yang mereka hadapi sehingga dengan begitu performa mereka akan lebih baik dalam ujian nanti karena telah terbiasa menghadapi kondisi tersebut. ${ }^{14}$

\section{Hubungan Tingkat Kecemasan dalam Menghadapi OSCE dengan Kelulusan OSCE}

Sejumlah 34 orang responden diketahui bahwa sebanyak 26 responden tidak mengalami kecemasan ketika menghadapi OSCE, enam belas orang diantaranya lulus $(61,5 \%)$ dan sepuluh orang lainnya tidak lulus (38,5\%). Dari delapan responden yang mengalami kecemasan ringan, enam diantaranya lulus (75\%) dan dua orang lainnya tidak lulus (25\%) dalam OSCE.

Ditinjau dari persentase kelulusan ditemukan bahwa pada peserta yang mengalami kecemasan ringan memiliki persentase kelulusan yang lebih tinggi.

Hal ini sesuai dengan penjelasan Astuti dan Resminingsih (2010) bahwa kecemasan pada tingkat ringan justru berefek positif bagi pelajar karena dapat memotivasi belajar serta menghasilkan pertumbuhan dan kreativitas sehingga persiapan dalam ujian akan lebih baik. ${ }^{15}$

Berdasarkan uji korelasi statistik didapatkan hasil koefisien korelasi $(r)=-0,106$ yang menunjukkan bahwa korelasi antara kecemasan menghadapi OSCE 
dengan kelulusan OSCE pada mahasiswa FK Unand adalah tidak ada/sangat lemah dengan arah korelasi negatif. Sedangkan nilai $p$ yang diperoleh yaitu sebesar 0,461 ( $p>0,05)$. Hal ini berarti bahwa tidak terdapat hubungan yang bermakna antara tingkat kecemasan mahasiswa FK Unand dalam menghadapi OSCE dengan kelulusan OSCE. Artinya kecemasan dalam menghadapi OSCE bukan merupakan salah satu faktor yang memberikan kontribusi terhadap kelulusan mahasiswa. Hal serupa ditemukan pada penelitian Asni et al (2013) yang dilakukan di FK Universitas Riau pada mahasiswa angkatan 2011 diketahui tingkat kecemasan tidak memiliki hubungan dengan hasil OSCE. ${ }^{16}$

Brand dan Schoonheim (2009) juga menemukan bahwa tidak ada hubungan yang signifikan antara tingkat kecemasan dengan performa mahasiswa ketika ujian. $^{8}$

Penelitian ini memiliki beberapa keterbatasan, namun harus diakui dan dipertimbangkan ketika menginterpretasikan hasil penelitian. Pertama, tidak ada responden yang mengalami kecemasan sedang, berat, dan berat sekali sehingga peneliti tidak dapat membandingkan data antara tingkat tidak ada kecemasan dan kecemasan ringan dengan kecemasan pada tingkat sedang, berat, dan berat sekali. Kedua, seluruh responden mengikuti OSCE untuk yang pertama kali sehingga peneliti tidak dapat membandingkan data antara peserta yang mengikuti OSCE untuk pertama kali dengan yang mengikuti OSCE lebih dari satu kali. Ketiga, peneliti melibatkan tim dalam proses penelitian yang berjumlah lima belas orang yang bertujuan untuk mencegah adanya peserta ujian yang lolos dari proses pengambilan data. Sebelum penelitian, dilakukan penyamaan persepsi kepada tim pewawancara. Namun demikian, kemungkinan bias terhadap data yang diperoleh tidak dapat dihindari. Keempat, berdasarkan survei awal yang dilakukan pada OSCE I TA 2012/2013, peneliti melakukan survei beberapa menit sebelum OSCE dimulai, namun banyak peserta yang menolak menjadi responden. Oleh karena itu ketika penelitian, peneliti melakukan wawancara sehari sebelum OSCE. Akan tetapi hasilnya banyak responden yang tidak mengalami kecemasan menjelang OSCE.

\section{KESIMPULAN}

Tidak terdapat hubungan yang bermakna antara tingkat kecemasan dalam menghadapi OSCE dengan kelulusan OSCE pada mahasiswa FK Unand.

\section{DAFTAR PUSTAKA}

1. Akbar R, Hawadi. Psikologi perkembangan anak, mengenal sifat, bakat, dan kemampuan anak. Jakarta: Grasindo; 2001.

2. Konsil kedokteran Indonesia. Standar pendidikan profesi dokter. Jakarta: Konsil kedokteran Indonesia; 2006.

3. Fakultas Kedokteran Universitas Andalas. Peraturan akademik program pendidikan dokter. Padang: Andalas University Press; 2010.

4. Dent JA, Harden RM. A practical guide for medical teachers. Edisi ke-2. China: Elsevier; 2006.

5. Kaplan HI, Sadock BJ, Greeb JA. Sinopsis psikiatri. Jilid ke-2. Wiguna IM, editor penterjemah. Jakarta: Binarupa Aksara; 2008.

6. Hawari D. Psikometri alat ukur (skala) kesehatan jiwa. Jakarta: Fakultas Kedokteran Universitas Indonesia; 2009.

7. Arief, Suwadi, Sumarni. Hubungan kecemasan menghadapi ujian skills lab modul shock dengan prestasi yang dicapai pada mahasiswa FK Universitas Gajah Mada angkatan 2000. (diunduh 5 Mei 2013). Tersedia dari: URL: HYPERLINK http://www.ebookspdf.org/download/kecemasan.ht $\underline{\mathrm{ml}}$.

8. Brand HS, Schoonheim-Klein M. Is the OSCE more stressfull? examination anxiety and its consequences in different assesment methods in dental education. European Journal of Dental Education. 2009;13(3):147-53.

9. Muldoon K, Biesty L, Smith V. 'I found the OSCE very stressful': student midwives' attitudes towards an objective structured clinical examination (OSCE).Nurse Education Today.2013;34(3):468-34

10. Colbert-Getz JM, et al. How do gender and anxiety affect students'self-assasment and actua performance on a high-stakes clinical skills examination?. Academic medicine. 2013; 88(1): 44-8. 
11. Brizendine $L$. The female brain. Cahayani $A$, editor penterjemah. Jakarta Selatan: Ufuk press; 2006.

12. Agustiar W, Asmi Y. Kecemasan menghadapi ujian nasional dan motivasi belajar pada siswa kelas XII SMA Negeri "X" Jakarta Selatan. Jurnal Psikologi. 2010;8(1):9-15

13. Mariyam, Kurniawan A. Faktor-faktor yaang berhubungan dengan tingkat kecemasan orang tua terkait hospitalisasi anak usia toddler di BRSD RAA Soewonso Pati. Jurnal keperawatan. 2008; $1(2): 38-56$
14. Fidment S. The OSCE: A qualitative study exploring the healthcare student's experience. Student engagement and experience journal. 2012;1(1):1-18

15. Astuti ES, Resminingsih. Bahan dasar untuk pelayanan konseling pada satuan pendidikan menengah. Jilid ke-1. Jakarta: Grasindo; 2010.

16. Asni E, Dafitra A, Risma D. Anxiety level in dealing with the OSCE: do they influence student performance?. Proceeding of the 10th Asia Pacific Medical Education Conference; 2013 Jan 16-20. Singapore: National University of Singapore; 2013. 